\title{
Indeks Glisemik Kacang Buncis (Phaseolus vulgaris) dan Kacang Panjang (Vigna sesquipedalis) serta Uji Efek Hipoglisemiknya pada Tikus Sprague Dawley
}

\author{
Snap Bean (Phaseolus Vulgaris) and Yardlong Bean (Vigna sesquipedalis): Glycemic \\ Index and Its Hypoglycemic Effect in Sprague Dawley Rats
}

\author{
Y. Marsono*, Priyanto Triwitono dan Sri Kanoni \\ Laboratorium Pangan dan Gizi, Jurusan Teknologi Pangan dan Hasil Pertanian \\ Fakultas Teknologi Pertanian, UGM *Penulis untuk Korespondensi
}

\begin{abstract}
Glycemic index (GI) of foods has been suggested as an additional parameter in selecting foods for the diabetic patients in nutritional management. GI was measured as the area under the postprandial blood glucose curve for a food expressed as a percentage of the area after the consumption of reference food (bread). In this research two legumes were investigated including snap bean (Phaseolus vulgaris L.) and yardlong bean (Vigna sesquipedalis). The objectives of this research were (i) to determine the IG of the beans and (ii) to investigate the effects of these legumes on serum glucose concentration of alloxan-induced diabetic rats. Ten health and normal volunteers (not diabetic) were provided. The volunteers took an overnight fasting, blood were drawn in the morning and analyzed for serum glucose. Then they were given the test beans containing total carbohydrates equivalent to 25 -g glucose to be consumed. Blood samples were drawn for glucose measurement every 30 minutes until 120 min after meal. Serum glucose was determined enzymatically and the glucose responses were drawn graphically to calculate the GI of the beans. These beans were evaluated for their hypoglycemic properties in alloxan-induced diabetic rats. They were fed modified AIN 93 diets contain $20 \%$ of energy derived from snap bean or yardlong bean for 28 days. Serum glucose concentrations were measured weekly. It was found that with white bread as the food standard the GI of the snap bean and yard long bean were 43 and 86, respectively. In 28 days of diet intervention, snap bean decreased the serum glucose level by $73 \%$ (from $212 \mathrm{mg} / \mathrm{dL}$ to $56 \mathrm{mg} / \mathrm{dL}$ ). Similar effect were found for the yardlong bean. This bean can reduced serum glucose level about $73 \%$ (from $224 \mathrm{mg} / \mathrm{dL}$ top $61 \mathrm{mg} / \mathrm{dL}$ ), but both were similar to control diet that decreased the serum glucose level about $72 \%$.
\end{abstract}

Key words : Glycemic Index, Snap bean, Yardlong bean, hypoglycemic, glucose response

Diterima : 02 Maret 2005, disetujui : 21 Juni 2005

\section{Pendahuluan}

Prevalensi penyakit diabetes militus di Indonesia dari tahun ke tahun selalu meningkat, mecapai sekitar dua juta saat ini dan diperkirakan mencapai lima juta pada tahun 2020 nanti (Gunawan dan Tandra, 1998). Penyakit ini dapat dicegah atau dikurangi dengan pengaturan diet yang tepat, yaitu membatasi asupan kalori dan memilih makanan yang memiliki Indeks Glisemik yang rendah, sebab makanan tersebut akan memberikan respon glukosa yang rendah setelah dikonsumsi. Oleh karena itu tersedianya informasi mengenai jenis makanan yang memiliki Indeks Glisemik yang rendah sangat mutlak diperlukan. 
Menurut Truswell (1992), Indeks Glisemik dapat didefinisikan sebagai ratio antara luas kurva glukosa darah makanan yang diuji yang mengandung karbohidrat total setara 50 gram gula, terhadap luas kurva glukosa darah setelah makan 50 gram glukosa, pada hari yang berbeda dan pada orang yang sama. Kedua test tersebut dilakukan pada pagi hari setelah puasa satu malam dan penentuan kadar gula dilakukan selama dua jam. Dalam hal ini, glukosa atau roti tawar dipakai sebagai standar (dengan nilai 100) dan nilai Indeks Glisemik makanan yang lain merupakan persen terhadap standar tersebut.

Meskipun di negara barat telah banyak publikasi mengenai Indeks Glisemik, di Indonesia daftar Indeks Glisemik masih sangat terbatas. Marsono (2001) telah mengadakan penelitian untuk mengetahui IG beberapa makanan sumber karbohidrat khas Indonesia. Dengan menggunakan relawan sebanyak 11 orang yang berkadar gula normal (bukan penderita diabet), dilaporkan bahwa ubi (Dioscorea alata LINN) memiliki IG terendah diantara makanan yang diuji, yaitu 73 . Sementara beras memberikan nilai 80 serupa dengan hasil yang dilaporkan oleh Miller et al., 1992. Sedangkan singkong, sukun dan pisang berturut-turut 78, 90 dan 92 dan sorghum mempunyai Indeks Glisemik 161. Berdasar temuan tersebut Marsono (2001) menyimpulkan bahwa sorgum, pisang dan sukun tidak baik sebagai pengganti nasi sedang singkong setara dengan nasi. Bahan yang memberi harapan sebagai pengganti nasi adalah ubi atau uwi (bhs Jawa). Beberapa umbi-umbian lain yang dilaporkan oleh Marsono (2002a) memiliki indek glisemik sangat bervariasi, misalnya kimpul, gembili dan ubi jalar masing-masing 95, 90 dan 179 sedang ganyong dan garut 105 dan 14. Penelitian terakhir menyebutkan bahwa kacang hijau, kacang tunggak dan kacang gude memiliki indek glisemik masing-masing 76, 51 dan 35; sedang kedelai, kacang kapri dan kacang merah memiliki indek glisemik berturut-turut 31, 30 dan 26. (Marsono et al., 2002).

Mengingat kacang-kacangan merupakan jenis makanan yang sangat populer di Indonesia, kiranya informasi mengenai Indeks
Glisemik bahan tersebut sangat diperlukan. Terlebih lagi kalau dikaitkan dengan salalu naiknya prevalensi penderita diabetes. Informasi mengenai indeks Glisemik kacangkacangan serta uji sifat hipoglisemiknya akan sangat bermanfaat dalam upaya pemilihan makanan yang dapat mencegah kenaikan gula darah. Konfirmasi nilai Indeks Glisemik dengan efek hipoglisemiknya pada hewan coba maupun manusia memang belum banyak dilakukan. Padahal hal tersebut sangat diperlukan, sebab nilai IG hanya ditentukan sesaat sedang konfirmasi secara in vivo dilakukan dalam jangka lebih panjang, sehingga lebih menggambarkan secara nyata dalam aplikasinya. Marsono et al., (2003) melaporkan bahwa kacang merah yang memiliki Indeks glisemik 26 lebih rendah daripada kedelai (31) ternyata juga memiliki kemampuan penurunan gula darah pada tikus yang lebih besar pula yaitu 69\% dibanding $65 \%$ selama 28 intervensi diet. Sebelumnya Marsono (2002b) juga melaporkan bahwa kacang kapri memiliki kemampuan penurunan gula darah secara in vivo sebesar $67 \%$ setara dengan nilai Indeks Glisemiknya.

Secara keseluruhan penelitian ini terdiri dari dua tahap penelitian. Tahap pertama berupa penentuan Indeks Glisemik kacang panjang (Vigna sesquipedalis) dan buncis (Phaseolus vulgaris) dan tahap ke dua berupa bioassay untuk menguji sifat hipoglisemik kedua kacang tersebut pada tikus Sprague Dawley yang diinduksi diabetes dengan injeksi aloksan. Penelitian ini bertujuan :

a. Untuk mendapatkan daftar Indeks glisemik dua macam kacang yang sampai saat ini belum tersedia di Indonesia, yaitu kacang panjang dan buncis. Daftar ini sangat diperlukan bagi penderita diabetes sebagai acuan dalam pemilihan makanan yang boleh dikonsumsi dalam upaya mencegah kenaikan kadar gula darahnya.

b. Mengkonfirmasi sifat hipoglisemik kacang pada tikus Sprague Dawley yang telah dibuat menderita diabetes dengan injeksi alokksan. 


\section{Bahan dan Metode Penelitian}

\section{Bahan dan alat}

Bahan utama untuk penelitian adalah kacang panjang dan kacang buncis, diperoleh dari pasar lokal di DIY. Bahan kimia untuk analisis dengan kualitas pro analysis (Sigma, BDH atau E-Merck) dibeli di toko bahan kimia di Yogyakarta atau Jakarta. Campuran vitamin (AIN-93-VX) dan mineral (AIN-93-MX) dibeli dari ICN, Amerika.Untuk pengujian bioassay digunakan tikus jantan jenis Sprague-Dawley (SD) diperoleh dari Unit Pemeliharaan Hewan Percobaan (UPHP) UGM.

Peralatan yang digunakan dalam penelitian ini diantaranya ialah neraca analitik, timbangan, grinder, kandang tikus, dan perlengkapannya, syringe injeksi, microhematokrite tube, dan alat-alat bedah. Sentrifuse kecil Hettich EBA III, Spectrofotometer (UV -1201 Shimadzu), vortex (Genie 2 model G-S60E), micro pipet, dan alat-alat gelas lainnya.

\section{Cara penelitian dan analisis}

\section{a. Penentuan Indeks Glisemik}

Analisis kadar air, total pati dan total gula (AOAC. 1970) dilakukan terhadap sampel yang telah mengalami pengukusan hingga masak (siap makan). Berdasar data kandungan gula dan pati sampel yang telah dikukus dapat dilakukan perhitungan jumlah sampel yang harus dimakan oleh relawan dalam penentuan Indeks glisemik, yaitu mengandung 25 gr setara glukosa. Relawan (10 orang) berpuasa selama 10 jam mulai malam hari, kemudian pada pagi harinya darah diambil dan dianalisis kadar gulanya (gula puasa). Kemudian kepada relawan diberikan makanan yang akan diuji Indeks Glisemiknya dengan berat yang telah ditentukan (mengandung 25 gr setara glukosa). Pengambilan darah dan analisis gula darah diulangi lagi dengan interval 30 menit setelah makan, sebanyak 4 kali (30 menit, 60 menit, 90 menit dan 120 menit). Dari kadar gula darah puasa dan setelah makan dapat dibuat grafik respon glukosanya dan dapat ditentukan Indeks Glisemiknya. Indeks Glisemik merupakan ratio luas kurva respon glukosa makanan yang diuji dengan luas kurva respon glukosa makanan standar (roti tawar). Kadar glukosa darah ditentukan dengan metoda ensimatis (Barham and Trinder, 1972, Kaplan and Szabo, 1983).

\section{b. Uji efek hipoglisemik secara in vivo}

Digunakan 24 ekor tikus yang dibagi menjadi tiga kelompok yaitu kelompok standar (ST), kacang panjang (KP), kacang buncis (KB), masing-masing delapan ekor. Tikus diinjeksi dengan alloksan $80 \mathrm{mg} / \mathrm{kg}$ berat badan (Marsono et al., 2001) sehingga diabetes (kadar gula darah lebih dari $200 \mathrm{mg} / \mathrm{dL}$ ). Tikus pada masing-masing kelompok diberi pakan standard (ST) dan pakan perlakuan (KP dan $\mathrm{KB}$ ). Diet standar (ST) disusun dengan formula AIN 93M (Reeves et al., 1993), sedang diet perlakuan (KP dan KB) seperti diet standar tapi $20 \%$ kalori berasal dari kacang yang diuji. Daftar komposisi pakan dapat dilihat pada Tabel 1.

Intervensi pakan dilakukan selama 28 hari, setiap hari konsumsi pakan diukur. Berat badan tikus dan kadar gula serum puasa dipantau setiap minggu. Pemeliharaan tikus dilakukan dalam kandang individual dengan suhu kamar dan ventilasi cukup. Darah diambil dengan teknik "orbital bleeding" (Baker et al., 1980) dan kadar glukosa serum ditentukan dengan metode GOD-PAP (fotometrik ensimatis) yang dikembangkan oleh Barham dan Trinder (1972). 
Tabel 1. Komposisi pakan

\begin{tabular}{lcccc}
\hline \multicolumn{1}{c}{ Bahan } & \multicolumn{4}{c}{ Jumlah komponen (g) untuk pakan } \\
& AIN 93* & Standar & K.Panjang (KP) & K.Buncis (KB) \\
\hline Casein (85\% prot) & 140 & - & - & - \\
Susu skim protifar (60\% prot) & & 199 & 87,8 & 127,7 \\
Tepung kacang panjang & & & 301,8 & - \\
Tepung kacang buncis & 620,7 & 621 & - & 216,1 \\
Maizena & 100 & 45 & 524,7 & 480,2 \\
Sukrosa & 40 & 38 & 57,9 & 44,6 \\
Minyak jagung & 50 & 50 & 36,4 & 36,9 \\
Cellulosa (CMC) & 35 & 21,7 & 28,7 & 48,8 \\
Camp. mineral AIN 93 Mx* & 10 & 4,6 & 7,5 & 6,4 \\
Camp. vitamin. AIN 93 VX * & 1,8 & 1,8 & 1,8 & 1,8 \\
L-sistine & 2,5 & 2,5 & 2,5 & 2,5 \\
Kholine bitartrat & 1000 & 983,6 & 1049,1 & 991 \\
Total & 3326 & 3326 & 3326 & 3326 \\
Kandungan Energi, Kcal & & & & \\
\hline
\end{tabular}

*) Sumber : Reeves et al., 1993, pakan AIN 93 adalah basal diet untuk acuan penyusunan pakan percobaan

\section{Hasil dan Pembahasan}

\section{Indeks glisemik kacang}

Untuk penentuan indeks Glisemik kacang pertama-tama dianalisis kadar total gula dan pati serta kadar air kacang yang sudah mengalami pengukusan 30 menit (siap makan) yang hasilnya disajikan pada Tabel 2. Berdasar komposisi tersebut dapat dihitung jumlah sampel yang harus dimakan oleh relawan untuk masing-masing kacang, pada penentuan Indeks Glisemik kacang.

Respon glukosa roti tawar, kacang panjang dan buncis setara 25 gr glukosa dapat dilihat pada Tabel 3 dan Gambar 1.

Tabel 2. Kadar air, pati dan total gula kacang panjang dan buncis kukus, \% wb serta berat makanan (kacang) uji yang haruis dimakan relawan (g) setara dengan 25 g glukosa

\begin{tabular}{lcccc}
\hline \hline Jenis kacang & \multicolumn{3}{c}{ Komponen bahan } & Berat \\
& Air & Pati & Total Gula & Makanan uji \\
\hline \hline Kacang panjang & $59,88 \pm 0,20$ & $14,58 \pm 0,16$ & $1,04 \pm 0,06$ & 146,39 \\
Buncis & $53,89 \pm 0,32$ & $17,27 \pm 0,65$ & $4,75 \pm 0,15$ & 105,28 \\
\hline \hline
\end{tabular}

Tabel 3. Kadar glukosa serum relawan (puasa dan post prandial) dengan makanan uji roti tawar, kacang panjang dan buncis setara 25 gr glukosa, $\mathrm{mg} / \mathrm{dL}$

\begin{tabular}{cccccc}
\hline \hline Makanan uji & \multicolumn{5}{c}{ Kadar Gula Darah Menit Ke- } \\
& $\mathbf{0}$ & $\mathbf{3 0}$ & $\mathbf{6 0}$ & $\mathbf{9 0}$ & $\mathbf{1 2 0}$ \\
\hline \hline Roti tawar & 76,38 & 86,74 & 91,34 & 78,95 & 79,96 \\
Kacang panjang & 67,05 & 83,99 & 77,36 & 73,37 & 76,20 \\
Buncis & 76,66 & 83,40 & 80,88 & 84,73 & 81,30 \\
\hline \hline
\end{tabular}

Untuk menentukan indeks glisemik kacang yang bersangkutan harus dihitung luar curva respon glukosa dengan base line kadar glukosa serum puasa. Oleh karena itu harus ditentukan perubahan kadar glukosa serum ponstprandial terhadap kadar glukosa serum puasa dan dibuat kurvanya seperti terlihat pada Gambar 2. 


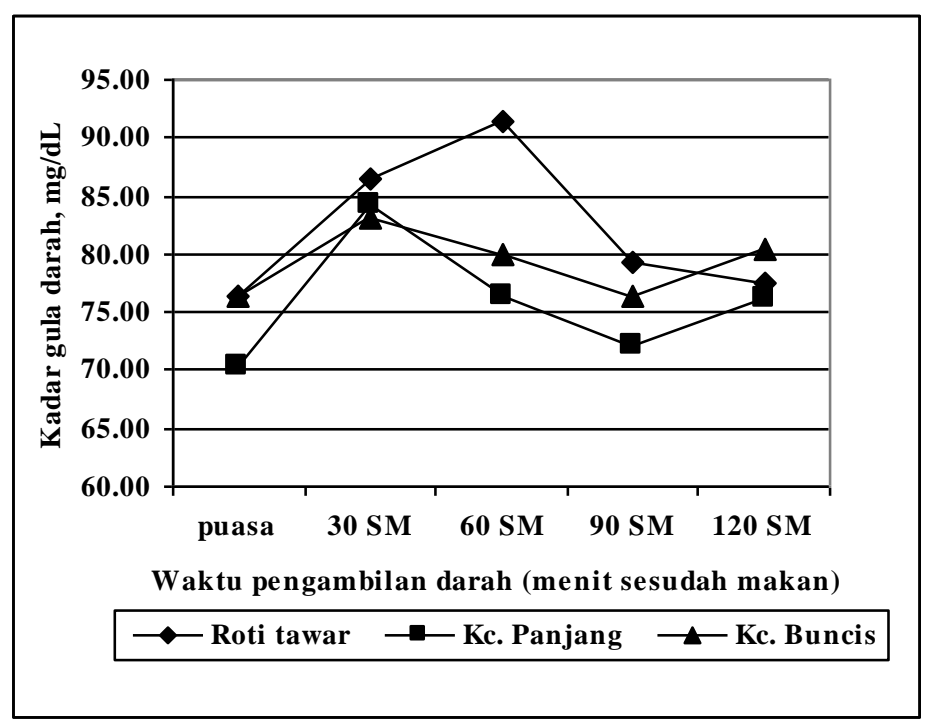

Gambar 1. Respon glukosa roti tawar, kacang panjang dan buncis setara 25 gr glukosa.

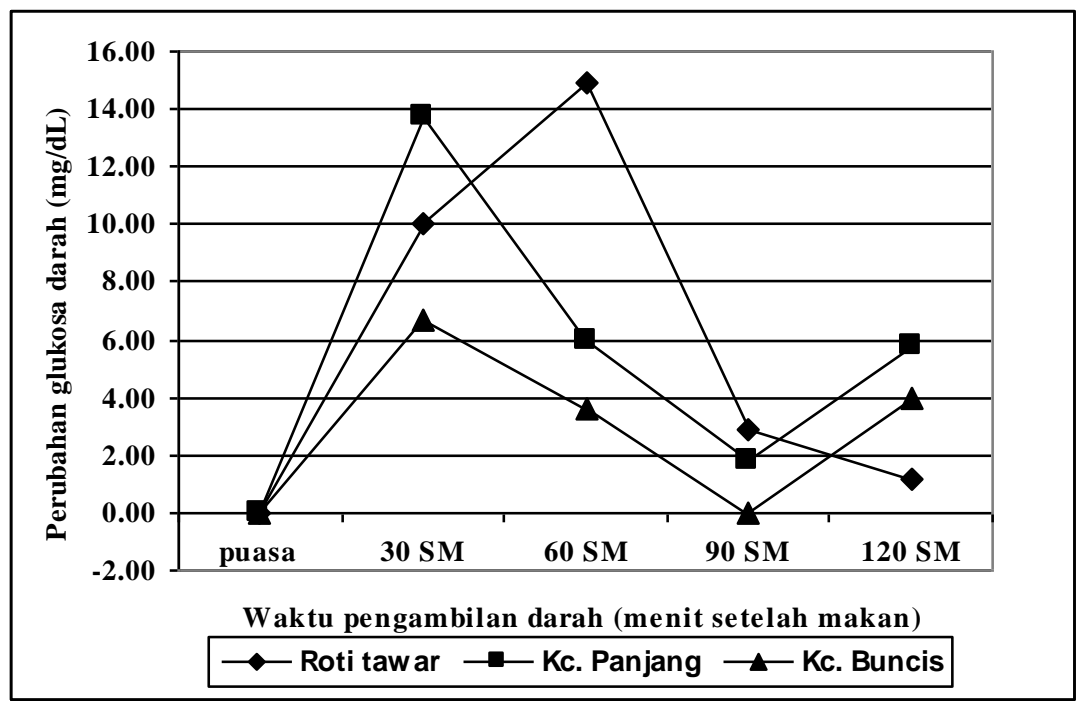

Gambar 2. Perubahan kadar glukosa serum setelah mengkonsumsi roti tawar, kacang panjang dan buncis setara 25 gr glukosa yang diamati selama 2 jam (kadar glukosa serum puasa sebagai titik nol)

Dari Gambar 2 tampak bahwa ada perbedaan puncak kadar glukosa serum dari sampel yang dijuji. Kacang panjang dan buncis memberikan puncak kadar glukosa pada menit ke 30 setelah makan sedangkan roti tawar pada menit ke 60. Data ini mengindikasikan bahwa proses pencernakan kacang dan absorpsi glukosa lebih lambat dibandingkan dengan roti tawar. Data yang menarik dari pengamatan ini adalah naiknya kembali kadar glukosa serum relawan yang makan kacang panjang dan buncis, setelah menit ke 90. Fenomena ini menggambarkan bahwa kedua kacang tersebut mengalami pencernakan yang lebih lambat sehingga bertahan lebih lama dalam sisitem pencernaan. Perhitungan nilai Indeks glisemik dapat dilihat pada Tabel 4 . 
Tabel 4. Indeks Glisemik Kacang panjang dan Kacang buncis (Standar roti tawar $=100$ )

\begin{tabular}{lc}
\hline \hline Makanan & lindeks glisemik \\
\hline \hline Roti tawar & 100 \\
Kacang panjang & 86 \\
Kacang buncis & 43 \\
\hline \hline
\end{tabular}

Dari hasil ini (Tabel 4) kacng buncis memiliki Indek glisemik yang rendah setara dengan beberapa kacang lain seperti yang dilaporkan oleh Marsono et al., 2002. Agak diluar dugaan bahwa kacang panjang memiliki IG yang cukup tinggi (86) lebih tinggi dari kacang hijau (76) jenis kacang yang memiliki IG paling tinggi pada penelitian sebelumnya (Marsono et al., 2002a) bahkan angka tersebut juga lebih tinggi dari IG garut yang hanya 14 (Marsono, 2002a) atau bahkan lebih tinggi dari beras, singkong dan uwi yang masing-masing memiliki IG 80, 78 dan 73 (Marsono, 2001).
Apakah faktor penyebabnya perlu kajian lebih lanjut.

\section{Bioassay untuk menguji sifat hipoglisemik kacang panjang dan buncis.}

\section{a. Asupan pakan}

Asupan pakan tikus dengan tiga macam pakan yaitu pakan standar (ST), kacang panjang (KP) dan kacang buncis (KB) selama penelitian dapat dilihat pada Tabel 5 .

Tabel 5. Asupan pakan tikus yang mendapatkan pakan standar, kacang panjang dan buncis pada awal percobaan dan rerata per minggu selama percobaan (gr)

\begin{tabular}{lccccc}
\hline \hline Kelompok Pakan & Awal percobaan & Minggu ke-1 & Minggu ke-2 & Minggu ke-3 & Minggu ke-4 \\
\hline \hline Standar & $9,61^{\mathrm{ab}}$ & $10,73^{\mathrm{ab}}$ & $11,96^{\mathrm{b}}$ & $11,89^{\mathrm{a}}$ & $12,75^{\mathrm{a}}$ \\
Kc. Panjang & $7,77^{\mathrm{a}}$ & $7,10^{\mathrm{a}}$ & $13,13^{\mathrm{b}}$ & $13,88^{\mathrm{b}}$ & $13,23^{\mathrm{a}}$ \\
Buncis & $12,22^{\mathrm{b}}$ & $12,75^{\mathrm{b}}$ & $9,99^{\mathrm{a}}$ & $12,04^{\mathrm{a}}$ & $12,92^{\mathrm{a}}$ \\
Standar Error & 1,90 & 1,57 & 0,08 & 0,07 & 0,06 \\
\hline \hline
\end{tabular}

Keterangan: superskrip dengan hurup sama pada kolom yang sama $(a, b)$ menunjukkan tidak beda nyata $(\mathrm{p}<0,05)$

Dari data pada Tabel 5 tampak bahwa pada kelompok pakan standar asupan pakan terus mengalami kenaikan sejak awal percobaan, kelompok pakan kacang panjang mula-mula sedikit menurun tapi kemudian naik dengan pesat sedangkan kelompok kacang buncis terjadi penurunan pada minggu kedua lalu kembali normal. Pada minggu terakhir ketiga kelompok tikus mengkonsumsi dengan jumlah yang tidak berbeda nyata.

\section{b. Berat badan tikus}

Berat badan tikus selama percobaan dapat dilihat pada Gambar 3. Tampak pada gambar tersebut bahwa untuk semua kelompok pakan, berat badan tikus mula-mula mengalami penurunan pada minggu pertama tetapi kemudian secara perlahan terjadi kenaikan. Data ini sangat selaras dengan data mengenai asupan pakannya. Penurunan berat badan pada awal percobaan sangat mungkin disebabkan oleh pengaruh injeksi alokson untuk menginduksi diabetes, sebab dengan injeksi tersebut tikus kemungkinan mengalami kesakitan. Pengamatan serupa juga pernah dilaporkan oleh Wisaniyasa et al., (2001), Marsono (2002b) dan Marsono et al., (2003). Pada akhir percobaan kelompok tikus yang mendapat pakan kacang panjang memiliki berat badan yang relatip lebih besar daripada kelompok lainnya sesuai dengan asupan pakannya pula. 


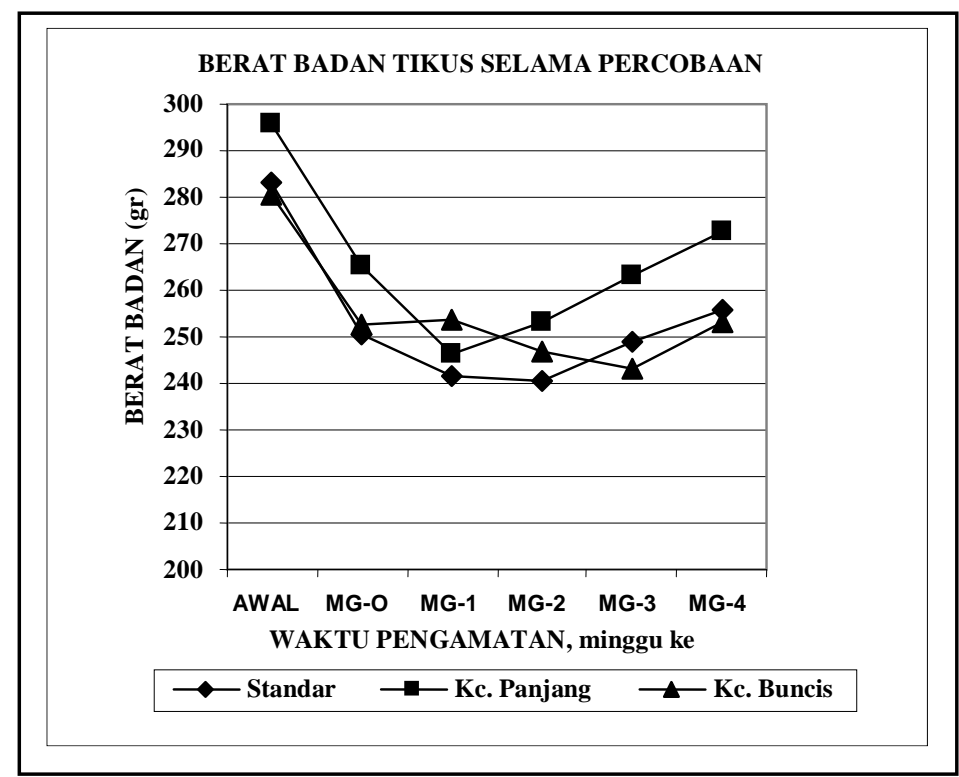

Gambar 3. Berat badan tikus yang mendapatkan pakan standar, kacang panjang dan kacang buncis selama empat minggu intervensi.

\section{c. Kadar gula serum}

Kadar gula serum tikus yang mendapat tiga macam pakan (standar, kacang panjang dan kacang buncis) dapat dilihat pada Gambar 4. Pada minggu pertama tampak bahwa injeksi aloksan sangat efektip untuk menaikkan kadar gula darah tikus sampai pada tingkatan diabetik (> $200 \mathrm{mg} / \mathrm{dL}$ ). Pengamatan pada minggu berikutnya menunjukkan bahwa ketiga kelompok mengalami penurunan glukosa serum dengan signifikan dan pada akhir percobaan untuk ketiga kelompok memiliki kadar glukosa serum yang tidak berbeda nyata. Hasil ini agak berbeda dengan yang dilaporkan oleh peneliti sebelumnya (Wisaniyasa et al., 2001; Marsono, 2002b dan Marsono et al., 2003). Wisaniyasa melaporkan bahwa dengan diet kontrol (AIN 93) setelah injeksi terjadi kenaikan glukosa daerah sangat signifikan dan pada minggu berikutnya meskipun terjadi penurunan hanya sangat kecil, berbeda dengan pakan perlakuan (protein kedelai) yang penurunannya sangat nyata.

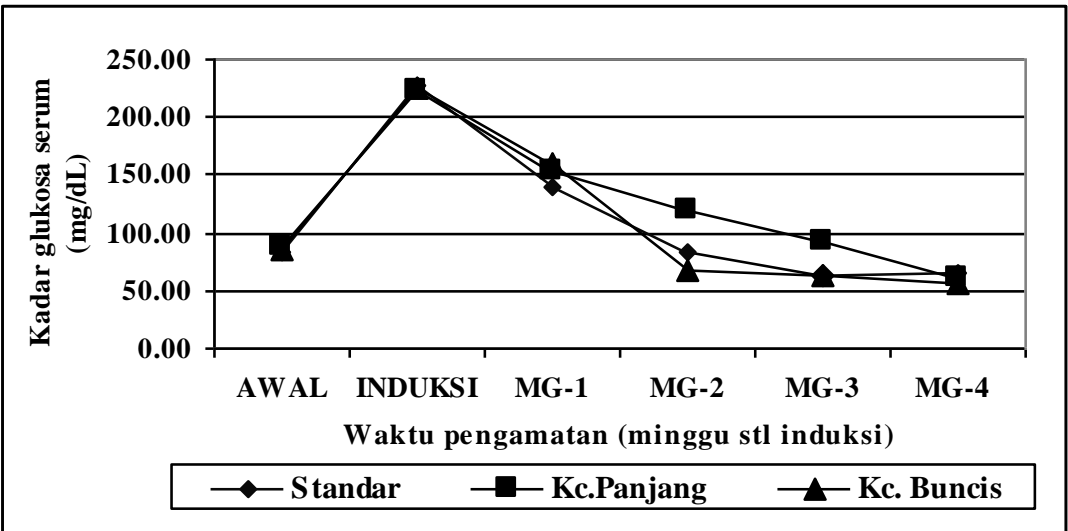

Gambar 4. Kadar glukosa serum tikus yang mendapatkan pakan standar, kacang panjang dan kacang buncis selama empat minggu intervensi. 
Marsono (2002b) ataupun Marsono et al., (2003) melaporkan bahwa meskipun pada kelompok tikus yang mendapat diet standar juga mengalami penurunan pada masa intervensi empat minggu, tetapi pada akhir percobaan kadar glukosa serum kelompok standar masih jauh lebih tinggi dibanding kelompok pakan perlakuan.

Data dari penelitian ini menunjukkan bahwa baik kacang panjang maupun kacang buncis yang dikonsumsi dengan proporsi $20 \%$ kalori tidak efektif untuk menurunkan kadar glukosa serum karena hanya sama dengan pakan standar. Kemungkinan lain diabetik yang dihasilkan dari induksi aloksan pada penelitian ini belum bersifat permanen meskipun konsentrasi glukosa serum sudah mencapai diatas $200 \mathrm{mg} / \mathrm{dL}$, tetapi masih pada tahap gangguan toleransi yang bersifat labil. Hal ini bisa terjadi kalau aloksan yang diberikan belum mengakibatkan kerusakan permanen dari sel beta pankreas yang bertangguang jawab untuk menghasilkan insulin. Kerusakan sementara masih sangat mungkin diperbaiki dengan berbagai perlakuan misalnya pemberian diet yang bersifat hipoglisemik.

\section{Kesimpulan dan Saran}

\section{Kesimpulan}

Dengan menggunakan roti tawar sebagai bahan referensi (indek glisemik $=100$ ), kacang panjang dan buncis memiliki indeks glisemik masing-masing 86 dan 43. Ini berarti kacang buncis lebih efektif untuk menurunkan kadar gula darah post prandial (setelah makan). Tetapi pada tikus, konsumsi dalam jangka panjang (28 hari) dengan proporsi $20 \%$ total asupan kalori kedua kacang tersebut tidak efektif dalam menurunkan kadar glukosa serum.

\section{Saran}

Dalam penelitian dengan hewan coba untuk induksi dengan aloksan perlu ditunggu stabilitasnya beberapa hari sebelum diberi perlakuan pakan percobaan dilakukan.

\section{Ucapan Terima Kasih}

Diucapkan banyak terima kasih kepada Direktur projek QUE Program Studi Teknologi Pangan dan Hasil Pertanian (TPHP), Fakultas Teknologi Pertanian UGM, atas biaya penelitian yang diberikan. Juga disampaikan ucapan terima kasih kepada Bp. Sukardjo atas bantuannya sampling darah, Rohmah, Yuli, Siwi dan Dedy atas bantuannya dalam persiapan dan analisis.

\section{Referensi}

Association of Official Analytical Chemist, 1970. Official methods of analysis, AOAC, Washington.

Baker, H.J., Lindsey, J.R. and Weisbroth, S.H. 1980. The laboratory rat, Vol. 2, Academic Press, New York.

Gunawan, A. dan Tandra, H. 1998. Patogenesis diabetes mellitus Tidak tergantung Insulin (DMTII). Pusat Diabetisi dan Nutrisi RSUD. Dr. Soetomo-FK. Unair. Majalah Diabetes. Vol.4 No.1. Surabaya

Kaplan, A. and Szabo, L.L. 1983. Clinical Chemistry: Interpretation and techniques. Second edition, Lea and Febiger, Philadelphia.

Marsono, Y. 2001. Glycemic Index of selected Indonesian starchy foods. Indonesian Food and Nutrition Progress: 8 : 15-20.

Marsono, Y., Wiyono, P. dan Zuheid Noor. 2001. Penentuan indek glisemik kacang-kacangan, factor determinan dan uji sifat hipoglisemiknya. Laporan penelitian Proyek Hibah bersaing IX tahun ke 1, Universitas Gadjah Mada.

Marsono, Y., Wiyono, P. dan Zuheid Noor. 2002. Index Glisemik kacang-kacangan. Jurnal Teknologi \& Industri Pangan XIII (3): 211-216.

Marsono, Y. 2002a. Penentuan indek glisemik umbiumbian. Agritech 22 (1): 13-16.

Marsono, Y. 2002b. Sifat hipoglisemik dan hipokolesterolemik kacang kapri (Pisum sativum LINN) dan kedelai (Glycine max MERR) pada tikus Sprague Dawley diabetik induksi alloksan. Agritech 22(4):137-143.

Marsono, Y., Zuheid Noor dan Fitri Rahmawati, 2003. Pengaruh diet kacang merah terhadap kadar gula darah tikus diabetik induksi alloxan. Jurnal Teknologi \& Industri Pangan XIV (1):1-6. 
Miller, J.B., Pang, E. and Brasmall, L. (1992). Rice: a high or low glycemic index foods. Am. J. Clin. Nutr. 56: 1034-6.

Reeves, P.G., Neilson F.H. and Fahey, G.C. 1993. AIN93. Purified Diets for laboratory Rodents: Final Refort of the American Institute of Nutrition Ad Hoc Writing Committe on the Reformulation of the AIN-76 A Rodent Diet. J.Nutr.123: 1939-1951

Truswell, A.S. (1992) Glycaemic index of foods. Eur. J. Clin. Nutr. 46 (Suppl;. 2): S91-S101. 